\title{
Tegur Sapa Penjual dan Pembeli di Pasar Tradisional Surya Kusuma Semarang
}

\author{
Sri Puji Astuti \\ Fakultas Ilmu Budaya, Universitas Diponegoro \\ sripujiastuti0116@gmail.com
}

\begin{abstract}
The market is where sellers and buyers meet. Meeting the sellers and buyers in traditional markets cause them to greet each other. For that purpose, they use the greeting word in interacting. What greetings are used in the traditional market of Surya Kusuma Semarang is discussed in this paper. Data collection was done by using observation method developed with basic technique of tapping and advanced technique in the form of notes technique and recording technique. Based on the results of research of greeting words used in traditional markets covers pronouns, relatives, limbs, title, profession, greeting intimate, and greeting where self. Speakers use greeting words by considering physical appearance, gender, and age. The greeting word is used by the seller to greet the buyer with the intention of captivating the buyer. Therefore, his merchandise is selling well.
\end{abstract}

Key word: greeting word, bayer, seller, and tradisional market

\section{Intisari}

Pasar merupakan tempat bertemunya penjual dan pembeli. Bertemunya penjual dan pembeli di pasar tradisional menyebabkan mereka saling bertegur sapa. Untuk kepentingan tersebut mereka menggunakan kata sapaan dalam berinteraksi. Kata sapaan apa sajakah yang digunakan di pasar tradisional Surya Kusuma Semarang dibahas dalam makalah ini. Pengumpulan data dilakukan dengan metode simak yang dikembangkan dengan teknik dasar sadap dan teknik lanjutan berupa teknik catat dan teknik rekam. Berdasarkan hasil penelitian kata sapaan yang digunakan di pasar tradisional meliputi kata ganti, kata kerabat, anggota tubuh, gelar, profesi, sapaan mesra, dan sapaan mana diri. Penutur menggunakan sapaan dengan mempertimbangkan tampilan fisik, jenis kelamin, dan usia. Kata sapaan mesra digunakan oleh penjual untuk menyapa pembeli dengan maksud memikat hati pembeli. Dengan demikian, barang dagangannya laris terjual.

Kata kunci: kata sapaan, penjual, pembeli, dan pasar tradisional

\section{Pendahuluan}

Pasar merupakan tempat bertemunya penjual dan pembeli. Antara penjual dan pembeli tentu mereka saling berkomunikasi. Di pasar peranan bahasa sangatlah penting karena di pasar tradisional sering ditemui tawar-menawar. Jarang sekali ditemui dalam pasar 
pembeli tidak menawar. Bahkan kegiatan tawar menawar meerupakan hal sangat menarik bagi pembeli.

Dalam kegiatan tawar-menawar tentu penjual dan pembeli saling menyapa. Jarang sekali ditemui di pasar tradisional penjual dan pembeli tidak saling menyapa. Bahkan penjual sering menyapa pembeli yang lewat di depan kiosnya. Dengan menyapa calon pembeli yang lewat diharapkan calon pembeli tertarik dengan barang dagangannya. Jadi, kenyataannya berbelanja di pasar tradisional selalu mengunakan kata sapaan. Dengan kata lain sebetulnya kata sapaan memegang peranan penting dalam transaksi jual beli. Kata sapaan dapat digunakan untuk mengawali komunikasi. Di samping itu kata sapaan juga digunakan untuk memperlancar komunikasi antara penjual dan pembeli. Berdasarkan latar belakang di atas permasalahan yang dibahas dalam makalah ini adalah apa sajakah kata sapaan yang digunakan di pasar Tradisonal Surya Kusuma Semarang?

Kata sapaan adalah kata yang dipakai untuk bertutur sapa (Kridalaksana, 1982). Kata sapaan ini digunakan untuk memanggil para pelaku dalam peristiwa bahasa. Menurut Badan Pengembangan dan Pembinaan Bahasa penggunaan kata sapaan itu sangat terikat pada adat-istiadat setempat, adat kesantunan, serta situasi dan kondisi percakapan.

Marihandono (dalam Ekowati,202:7-8) menyebutkan bahwa dalam bahasa Jawa terdapat bentuk-bentuk kata sapaan sebagai berikut:

a. Sapaan terhadap orang kedua tunggal nonkerabat yaitu kata ganti orang kedua kowe, panjenengann, panjenengan ndalem.

b. Sapaan nama diri misalnya Indra, Anton, Mbak Lina, dan Mas Edi.

c. Sapaan istilah kekerabatan misalnya Bapak, Ibu, Mbok, Mbakyu, Kakang, Jeng, Om dan Tante.

d. Sapaan Gelar pangkat atau profesi misalnya Bu Guru, Pak Lurah, dan Bu Dokter.

e. Kata benda agentif misalnya para sederek, para rawuh, dan panajenengen sedaya.

f. Bentuk nomina + -ku misalnya adikku, kakangku, dan kekasihku.

g. Bentuk deiksis misalnya kene dan kono.

$h$. Bentuk nominal misalnya sampeyan ndalem dan sampeyan. 
Kata sapaan kekerabatan unumnya juga digunakan untuk menyapa orang yang tidak mempunyai hubungan kekerabatan. Jadi, sebetulnya pemakaian kata sapaan ni mengalami perluasan makna. Contoh kata bapak dan ibu yang semula berarti 'orang tua'. Kata bapak dalam bahasa Indonesia digunakan untuk menyebut orang tua laki-laki, kata bapak juga secara umum digunakan untuk menghormati orang lain (Wardhaugh, 1998:224)

\section{Metode Penelitian}

Dalam penelitian ini dipilih pasar Surya Kusumo Semarang karena lokasi pasar ini terletak di perbatasan perkampungan, yaitu sebelah timur Desa Bugen, sebelah barat desa Dempel, dan sebelah utara Desa Ngablak. Kondisi tersebut menyebabkan baik pedadang maupun pembeli berasal dari beberapa desa sehingga kata sapaan yang digunakan lebih bervariasi. Pengumpulana data dilakukan dengan metode simak yang dikembangkan dengan teknik dasar sadap dan teknik lanjutan berupa teknik catat dan teknik rekam.

\section{Pembahasan}

Berdasarkan hasil penelitian kata sapaan yang digunakan di pasar Tlogosari Semarang adalah kata ganti, kata kerabat, anggota tubuh, gelar, sapaan profesi, sapaan mesra, dan nama diri.

\section{Kata Ganti}

Kata ganti yang digunakan penjual dan pembeli yaitu kata ganti orang orang kedua yaitu sampeyan dan panjenengan.

Berikut ini merupakan tuturan antara pembeli 1 dan pembeli 2.

(1) Pembeli 1 : "Panjenengan badhe masak napa?"

'Mau masak apa"

Pembeli 2 : "Tasih bingung badhe masak napa nggih?”

'Masih bingung mau masak apa'

Konteks tuturan: pembeli satu dan pembeli dua hidup bertetangga. Mereka bertemu di salah satu pedagang di pasar. Tuturan di atas sering dituturkan pada pembeli di pasar ketika pembeli sedang bingung mau memasak apa. Contoh di atas menggunakan kata sapaan orang kedua Panjenengan. Kata Panjenengan digunakan karena pembeli (1) dan 
pembeli (2) biasanya dalam berkomunikasi menggunakan bahasa Jawa Krama. Hal tersebut dikarenakan pembeli (2) lebih tua usianya dibandingkan dengan pembeli (1). Contoh di atas berdeda dengan contoh berikut ini

(2) Pembeli : " "Tahu baksoku endi Mbak?

'Tahu baksoku mana Mbak?'

Penjual ; "Wah ketinggalan di rumah"

“Terus piye ya?"

'Lalu bagaimana?'

“Sampeyan jukuk ya Mas!"

'Kamu ambil ya!'

Suami penjual : "Ya"

Konteks tuturan: dua hari yang lalu ada seorang pembeli yang memesan tahu bakso kepada penjual. Pembeli berjanji akan mengambil pesanan hari itu. Akan tetapi, penjual lupa membawa tahu bakso. Akhirnya penjual menyuruh suaminya mengambil pesanan yang tertinggal.

Dalam contoh di atas digunakan kata sapaan Sampeyan. Penjual tidak menggunakan kata sapaan kowe karena penjual ingin menghormati suaminya. Penjual memilih menggunakan kata sampeyan yang dianggap lebih menghormati suami. Kata sapaan Sampeyan digunakan karena hubungan kedekatan antara penutur dan mitra tutur.

Contoh lain pemakaian kata ganti orang kedua Panjenengan dan sampeyan.

(3) Pembeli : " Bu pesen ayam gangsal nggih?”

'Bu pesan ayam lima'

"Kula pendhet gasik ya Bu?"

'Saya ambil pagi ya Bu'

“Jenengan buka jam pinten?"

'Kamu buka pukul berapa?'

Penjual : : Jam gangsal kula sampun buka.”

'Pukul lima saya sudah buka'

Kata jenengan dalam contoh di atas digunakan untuk menyapa penjual. Kata jenengan ini biasanya digunakan untuk menyapa orang kedua. Kata jenengan biasanya digunakan dalam bahasa Jawa krama. Namun, dalam kenyataannya penutur yang menggunakan bahasa Jawa Ngoko pun menggunakan jenengan untuk menyapa mitra tuturnya. 
Pemakaian sapaan jenengan untuk menghormati mitra tutur. Hal tersebut juga dapat dilihat dalam cantoh berikut ini.

(4) Penjual 1 : "Bu Jenengan entuk undangan sunatan?"

'Ibu dapat undangan khitan?'

Penjual 2 :"Ya Bu mangkate bareng ya?"

'Ya Bu kita berangkat bersama ya?

\section{Kata Kerabat}

Kata kerabat yang digunakan dalam tuturan jual beli di pasar tradisional Surya Kusuma Semarang dapat diklasifikasikan menjadi sapaan kekerabatan untuk laki laki dan sapaan kekerabatan perempuan. Sapaan kekerabatan untuk laki-laki yaitu Pak, Dhe, Lik, Mas dan Pi. Sedangkan kata sapaan kekerabatan untuk penjual atau pembeli perempuan adalah $I b u, Y u, M b a k, M b a h$. Perhatikan contoh berikut ini.

(5) Pembeli : "Pak pisang sing iki pira Pak"

'Pak pisang yang ini berapa?'

$$
\begin{array}{cl}
\text { Penjual } \quad: \text { Telung puluh wae." } \\
\text { 'Tiga puluh saja' } \\
\text { Pembeli } \quad \text { :"Selawe wae ya Pak?" } \\
\\
\text { 'Dua puluh lima ya Pak? } \\
\text { Penjual } \quad \text { :" Wis tak korting rong ewu." } \\
\\
\text { 'Saya kurangi dua ribu' }
\end{array}
$$

Tuturan di atas merupakan tuturan antara penjual pisang dan pembeli. Mereka menggunakan bahasa Jawa ngoko. Pembeli pisang sudah berlangganan membeli pisang di situ. Hubungan penjual dan pembeli sudah kenal. Kata sapan Pak biasanya digunakan untuk menyebut orang tua laki-laki. Kata Pak ini mengalami perluasan makna. Sapaan Pak digunakan dalam tuturan tersebut karena pedadang dianggap sudah tua oleh pembeli. Jadi, sebetulnya pembeli menghormati penjual dengan menggunakan kata sapaan Pak

Contoh berikut ini merupakan tuturan yang menggunakan kata sapaan Mas.

(6) Pembeli

: "Mas tulung dicantholake blonjoku!"

'Mas tolong digantungkan barang belanjaku!'

Tukang parkiir :'Inggih Bu, sampun rampung?" 
'Ya Bu, sudah selesai?'

Pembeli : "Durung Mas."

'Belum Mas'

Ttuturan di atas merupakan tuturan antara pembeli dan tukang parkir di pasar. Agar tidak berat membawa barang belanjaan, pembeli biasanya menaruh barang belanjaannya di kendaraan. Namun, posisi kendaraan waktu itu sulit dijangkau pembeli sehingga pembeli minta tolong tukang parkir.

Pemakaian kata sapaan Mas biasanya digunakan untuk menyapa saudara tua laki-laki. Dalam tuturan di atas Mas digunakan untuk menyapa tukang parkir karena pembeli ingin menghormati tukang parkir meskipun usia tukang parkir lebih muda daripada pembeli.

Pemakaian kata sapaan Mbah juga dapat dilihat dalam contoh berikut ini.

(7) Penjual

$\begin{array}{ll}\text { Pembeli } 1 & \text { : 'Sup tigang ewu." } \\ & \text { 'Sup tiga ribu' } \\ \text { Pembeli } 2 & \text { : "Mbah titip blonjoku disik ya." } \\ & \text { 'Nek titip belanjaanku ya.' } \\ \text { Penjual } & \text { : "Ya Nok, selehke ning kono." }\end{array}$

: "Jenengan pripun Bu?"

'Kamu bagaimana, Bu?'
Tuturan di atas merupakan tuturan penjual sayur dengan pembeli 1. Ketika penjual sedang berbicara dengan pembeli 1 datanglah perempuan muda membawa barang belanja sambil menggendong anak. Perempuan muda tersebut menitipkan barangnya ke penjual

Kata sapaan Mbah biasanya digunakan untuk menyapa perempuan maupun lakilaki yang sudah tua. Pemakaian sapaan Mbah dalam wacana tersebut digunakan oleh perempuan muda untuk menyapa pedagang sayur. Kata sapaan Mbah merupakan kata sapaan yang mempunyai hubungan kekerabatan digunakan untuk menyebut seorang perempuan tua yang tidak mempunyai hubungan kekerabatan. Dalam contoh di atas pedagang menyapa perempuan muda dengan sapaan Nok. Sapaan Nok digunakan pedagang karena pedagang menganggap perempuan tersebut sebaya anak perempuannya. 


\section{Anggota Tubuh}

Kata sapaan yang berhubungan dengan anggota tubuh yang digunakan di pasar yaitu kata awakmu. Perhatikan contoh berikut ini.

(8) Penjual 1 :"Awakmu mau ning endhi tho?"

'Tadi kamu di mana?'

"Mau ana sing tuku duwite ning kono."

'tadi ada yang beli. Uang di situ'

Penjual 2 : "Matur nuwun."

'terima kasih'

“Aku mau lagi njukuk kunci motor."

'saya ambil kunci motor' ‘

Tuturan tersebut dituturkan oleh penjual tempe kepada penjual telur asin. Ada pembeli yang mau membeli telur asin tetapi penjual tidak ada. Oleh karena itu, penjual tempe yang ada disebelahnya melayani pembeli.

Peristiwa dalam tuturan di atas sering terjadi karena kadang-kadang penjual meninggalkan kiosnya tanpa pamit dengan tetangga sebelahnya. Dalam tuturan tersebut penjual tempe menggunakan sapan awakmu yang berarti 'kamu'. Pemakaian kata awakmu digunakan karena penutur dan mitra tutur hubungannya sangat akrab.

\section{Gelar}

Sapaan gelar yang digunakan di lingkungan pasar tradisional yaitu $B u$ haji. Perhatikan contoh berikut ini.

(9) Penjual : : "Bu Haji mriki badhe tumbas napa?"

'Bu haji ke sini mau beli apa?'

Pembeli : "Sayur asem Mbah."

'Sayur asem, Mbah'

Penjual : : Napa malih Bu Haji?"

'Apa lagi Bu Haji?'

Tuturan di atas terjadi pada waktu ada seorang perempuan lewat di depan penjual. Penjual menyapa perempuan tersebut dengan sapaan Bu Haji.

Tuturan dalam contoh di atas sering dijumpai di pasar tradisional. Sapaan $B u$ Haji biasanya digunakan untuk orang yang sudah pernah menunaikan ibadah haji. 
Penjual menyapa dengan sapaan $B u$ haji kepada pembeli. Sapaan tersebut dipakai karena penjual beranggapan bahwa orang yang lewat di depannya dianggap sudah pernah berangkat haji. Padahal yang dipanggil Bu Haji belum tentu sudah pernah menunaikan ibadah haji. Penjual menggunakan sapaan tersebut karena penjual melihat pembeli mengenakan jilbab. Jadi, pangilan tersebut digumakan atas dasar tampilan pembeli.

\section{Sapaan Profesi}

Sapaan profesi yang sering digunakan di lingkungan pasar tradisional yaitu Bu Guru. Perhatikan contoh berikut ini.

(10) Penjual : "Bu Guru manggo niki pisange ayu-ayu?"

'Bu Guru ini pisang bagus-bagus'

Pembeli :"Rajane sing tua ana Mbah?"

'Pisang rajanya ada yang tua, Mbah'

Penjual :" Niki Bu Guru."

'Ini Bu Guru'

Tuturan di atas merupakan tuturan penjual pisang kepada pembeli. Penjual menyapa pembeli dengan sapaan Bu Guru. Sama halnya dengan sapaan Bu Haji, sapaan Bu Guru terkadang digunakan oleh penjual kepada pembeli yang mengenakan pakaian batik. Akan tetapi, bisa jadi pembeli memang berprofesi guru atau bukan guru . Jadi, sebetulnnya tampilan seseorang seperti guru di lingkungan pasar tradisional terkadang disapa $B u$ Guru.

\section{Sapaan Mesra}

Dalam lingkungan pasar tradisional sering dijumpai pemakaian sapaan mesra Sayang. Perhatikan contoh berikut ini.

(11) Penjual

Pembeli
: "Sayang arep masak apa?"

'Sayang, mau masak apa'

"Iki lho kangkunge cantik-cantik."

'Ini lho kangkung cantik-cantik

: "Masak soto wae Mbak sing seger."

'Masak soto saja yang sgar' 
Sapaan mesra sayang digunakan penjual untuk menyapa pembeli. Pemakaian kata sapaan tersebut digunakan untuk memikat hati pembeli. Dengan digunakannya sapaan tersebut pembeli akan mendekat dan membeli barang dagangannya.

\section{Sapaan Nama Diri}

Sapaan nama diri juga dipakai di lingkungan pasar tradisional

(12) Penjual $1 \quad$; "Tien duwe trasi Yuwana?"

'Tien punya terasi Yuwana?'

Penjual 2 : "Ya duwe."

'Ya punya'

Dalam wacana di atas penjual menanyakan barang dagangan yang tidak dimiliki. Dalam contoh di atas digunakan kata sapaan nama diri. Panggilan tersebut digunakan karena hubungan penutur dan mitra tutur sangat akrab dan lebih muda.

\section{Simpulan}

Berdasarkan uraian di atas dapat disimpulkan bahwa dalam interaksi jual beli di pasar tradisional Suryo Kusumo Semarang digunakan kata sapaan yang bervariasi. Pemakaian kata sapaan di digunakan di pasar tradisional Suryo Kusumo Semarang yaitu kata ganti, kata kerabat, anggota tubuh, gelar, profesi, sapaan mesra, dan sapaan mana diri. Dalam menggunakan sapaan penutur mempertimbangkan tampilan fisik, jenis kelamin, dan usia. Kata sapaan mesra digunakan oleh penjual untuk menyapa pembeli dengan maksud memikat hati pembeli. Dengan demikian, barang dagangannya laris terjual.

\section{Daftar Pustaka}

Ekowati, Endah.2002. "Sistem Sapaan Masyarakat Keturunan Arab di Kelurahan Dadapsari Semarang Utara. Skripsi, Fakultas Sastra Universitas Diponegoro.

Badan Pembinaan dan Pengembanga Bahasa. "Kata Sapaan Dalam Bahasa Indonesia"http://badanbahasa.kemdikbud.go.id/lamanbahasa/petunjuk_praktis/49 5/Kata\%20Sapaan\%20Dalam\%20Bahasa\%20Indonesia (diunduh 12 Agustus 2016)

Kridalaksana, Harimurti.1982. 'Dinamika Tutur Sapa dalam Bahasa Indonesia" dalam Moelyono (Ed) Pelangi Bahasa. Jakarta:Bathara Karya Aksara.

Wardhaugh, Ronald.1998. An Introduction to Sociolinnnnnguistic. Oxford:Blackweell publishrs. 